\title{
DURKHEIM ON MORAL InDIVIDUALISM, Social Justice, and Rights: A Gendered Construction of Rights ${ }^{1}$
}

\author{
MarCela CRISTI
}

\begin{abstract}
A standard interpretation of Durkheim's theory of individualism is that he advocated the rights and dignity of the individual, and a social order based on the principles of equality and justice. Contemporary scholars discuss his notion of individual rights in neutral terms, as if Durkheim applied it equally to both sexes, ignoring the fact that women are excluded from Durkheim's vision of a just society. This article places Durkheim's theory of moral individualism and social justice in the context of his views on women, and offers a critique both of his theory and its present-day interpretation. It is argued that his reputation as defender of human rights is undermined by his theoretical treatment of the female sex. Durkheim refers to the "individual" in generic terms, but his approach to a just social order and rights is essentially formulated in terms of the "social" male individual.
\end{abstract}

Key words: individualism, moral individualism, individual rights, social justice, gender inequality, gender relations.

Résumé: Une interprétation classique de la théorie durkheimienne de l'individualisme avance qu'elle défend les droits et la dignité de l'individu ainsi qu'un ordre social ancré dans les principes d'égalité et de justice. Or, les chercheurs contemporains discutent de manière plutôt neutre cette notion de droits individuels, comme si Durkheim les appliquait de manière équivalente aux deux sexes, ignorant par le fait même qu'il excluait les femmes dans son interprétation d'une société juste. Cet article porte un regard critique sur la théorie durkheimienne de l'individualisme moral et de la justice sociale dans le contexte de sa perspective sur les femmes ainsi que sur ses interprétations actuelles. La réputation de Durkheim, en tant que défenseur des droits de la personne, est minée par sa conceptualisation théorique de la femme dans la société moderne. Durkheim

1. Paper presented at Understanding the Social World Conference, July 2011, University of Huddersfield, UK. I would like to acknowledge the helpful comments provided by Lorne Dawson, University of Waterloo, on an earlier draft of this article. I would also like to thank Dr. Kevin D. Haggerty, the anonymous reviewers, and my husband, Renato Cristi, whose thoughtful suggestions and perceptive criticism greatly improved this final version. 
parle de "l'individu" en termes génériques, toutefois sa vision des droits et d'un ordre social juste est formulée à partir de l'individu "social" masculin.

Mots clés: individualisme, individualisme moral, droits individuels, justice sociale

\section{INTRODUCTION}

C) urkheim has been characterized as a conservative (Coser 1960; Nisbet 1952; Zeitlin 1981), a liberal (Strenski 2006; Lukes 1973; Prager 1981; Bellah 1973), a radical thinker with socialist tendencies (Pearce 2001; Gane 1992; Meštrović 1992; Emirbayer 2003; Giddens 1986), or even as the precursor of Fascism (in Bellah 1973:xxxi; Llobera 1994:141). But there is one side to Durkheim's work that no one appears to dispute. Commentators agree that Durkheim championed the rights and dignity of the individual (Cladis 1992:129-130; Stedman Jones 2001:49), that he sought to "enhance human freedom" (Prager 1981:919), and that he was deeply concerned "with the implementation and the furtherance of individual rights" (Giddens 1986:3). There is wide agreement that his theory of moral individualism espouses a universal value system that stresses the importance of individual rights and freedom, and a world order based on the principles of equality and social justice.

There is a problem with this consensus. Contemporary scholars, in the English-speaking literature, read and interpret Durkheim's notion of moral individualism, and use the language of individual rights, in neutral terms, as if it could be applied equally to both sexes. His theory is presented as a concern for the rights of others (Tole 1993:3, see also Bellah 1973, Seidman 1985) and, hence, as supporting the rights of women. But scholars generally overlook the fact that Durkheim's commitment to the free individual does not relate to "humankind," but to "mankind."

Although there is an extensive scholarship and feminist critique on Durkheim's ideas on gender relations, suicide, law, religion (Lehmann 1994, 1991, 1990; Shope, 1994; Gane 1992; Kandal 1988; Sydie 1987; Tiryakian 1981; Johnson 1972; Besnard 1973), and a few authors have pointed out, in passing, that Durkheim's universalistic orientation "was marred by his exclusion" of the female sex (Llobera 2002:77; Barmaki 2008:57; Gane 1992:105; Cladis 1992:303fn14), the relationship between his theory of justice and freedom, and his views on women, has not been fully explored. The overwhelming majority of scholars dealing with his theory of moral individualism, present Durkheim as a champion of individual rights, and the theory itself as a "universal modern value 
system"(Cotterrell 2010:xi). ${ }^{2}$ Even feminist scholars have neglected his theory of moral individualism relative to other aspects of his writings. This paper aims to address this shortcoming.

While Durkheim's concern with the development of individual freedom in modern society is undeniable, I argue that his reputation as defender and protector of human rights, individual self-development, and social justice is undermined by his writings on the female sex. A society which excludes the interests and well-being of females, cannot be said to be a just society. To deny women's demand for freedom, equality, and in the end, justice, is to go against the essential tenets of moral individualism.

There are four parts to my analysis. The article begins with an examination of Durkheim's theory of moral individualism as traditionally understood and interpreted. The next section examines Durkheim's early theory of gender relations. The third segment analyzes his views on women in modern society. Both sections help explain why his theory of justice cannot be universally applied. The last piece deals with Durkheim's gendered construction of social justice and rights. I also discuss here a persistent problem in contemporary scholarship on moral individualism, namely the tendency to ignore that Durkheim excludes women from his vision of a just society.

\section{Moral Individualism}

For Durkheim, the malaise of modernity was the result of the profound structural changes that had occurred in a very brief period of time. In The Division of Labour, he laments that tradition has lost its controlling influence, and "individual judgment has been freed from collective judgment." Institutional functions have been "disrupted" and have not had time to prepare and adjust. The organization of the new social life has been unable to fulfill "the need for justice which has grown more ardent in our hearts" ([1893]1964:408-9). The fulfilment of this need is a moral task proper to the state.

But the state, as the guardian of public morality, cannot be just "a spectator of social life (as the economists would have it)." It "must be present in all spheres of ... life and make itself felt" ([1950]1992:72, 65). While its role is to regulate social life, the state has a nobler moral mission the protection and advancement of moral individualism ([1950]1992:71). A democratic state, Durkheim argues, has moral authority only to the

2. It is worth noting that the bulk of the literature on moral individualism has been written primarily by male scholars. 
degree that it guarantees and advances the self-realization, and the rights of the individual. This is the essence of its moral function.

Durkheim predicts that the profound structural changes in modern society will affect the way the sacred is experienced. He envisions that the sacred will be defined in terms of the individual. Social solidarity in the modern world will consist of the bonds between increasingly interdependent, yet autonomous individuals (Beckford 1989:26). In modern society, the conscience collective is diffused, leaving an "open place for a growing multitude of individual differences," but there is one belief that has become strengthened and universalized - the sacredness attributed to the individual. ${ }^{3}$ The human person, Durkheim notes, is becoming "the object of a sort of religion" ([1893]1964:172). He has come to share the "transcendent majesty" and the religious respect that all churches "lend to their gods." This explains why "an attempt on ... a man's liberty ... inspires in us a feeling of horror analogous ... to that which the believer experiences when he sees his idol profaned" ([1898]1973:46).

The creation of this world religion, which he variously called "moral individualism," the "religion of humanity," the "religion of the individual," or the "cult of man," was of the utmost importance, for sooner rather than later "members of a single social group will have nothing in common among themselves except their humanity." This form of individualism originates from a desire for greater justice and from "sympathy for all that is human" (Durkheim [1898]1973:51, 48-9).

Moral individualism, in short, "is a religion in which man is at once the worshiper and the god"(Durkheim [1898]1973:46). The "sacred" dimension of the modern individual finds its expression in the unique respect granted to him and in the protection of his rights. But there is no such thing as inherent rights and liberties. Modern society has "consecrated," him, granted him rights, and made him "worthy of respect" ([1906]1953b:72, [1906]1953a:58). Each individual embodies the universal values of humanity, each individual consciousness carries "something divine" and it is "marked with a character which renders it sacred and inviolable to others"([1898]1973:52). Durkheim is optimistic that moral individualism will become the "moral catechism" and the source of a new morality. He claims that the "cult of the individual" has become one of the most distinctive characteristic of modernity, and that it is replacing all other religions. This religion "has everything it needs to speak to its faithful in a no less imperative tone than the religions it replaces"

3. Durkheim anticipates here his own concern with collective representations, centered on the concept of the sacred, which emerges in later writings, especially in The Elementary Forms. 
([1898]1973:48). This modern morality is socially constructed, shared, and enforced (Marske 1987:3; Cladis 1992:41; Pearce 2001:167).

Durkheim attempts to solve a crucial problem of moral authority in modern society, which is found in the "confrontation of egoism and moral individualism" (Giddens 1986:11). He acknowledges that some forms of individualism are egoistic and threaten the common good by encouraging the individual to be self-seeking and self-interested. Moral individualism has to be distinguished from the "utilitarian egoism of Spencer and of the economists." It involves a morality of cooperation and a profound respect for humanity. It is not the "glorification" of the self, "but of the individual in general" (Durkheim [1898]1973:44, 48). At its "most abstract level," scholars have noted, it refers to humanity in general rather than to individuals of any particular nation-state (Giddens 1986:21). It stresses "freedom and dignity, not happiness, as highest social ends" (Terrier 2006:294).

Durkheim, thus, distinguishes between two types of individualism. One with its roots in the philosophy of Spencer and the utilitarians, which Durkheim felt threatened the unity of France. The other, moral individualism, is traced back to the philosophy of Rousseau and Kant. The former "reduces society to nothing more than a vast apparatus of production and exchange."The latter is characterized by its emphasis on those universal human rights which guided the French revolutionaries and became embodied in the Declaration of the Rights of Man ([1898]1973:44-5).

While Durkheim recognizes that religious institutions have been gradually losing power, he does not claim that the "functions which had traditionally been fulfilled by religion [are] also in decline" (Beckford 1989:26). Although its influence has diminished, religion will never wither away. Religion has for him a permanent and universal existence. But religion is not static; "the religion of yesterday" cannot be that "of tomorrow"(Durkheim [1898]1973:51). So no matter what form religion may take, societies will continue to possess a religious foundation. $\mathrm{He}$ even hoped that local nationalism would be eventually replaced by internationalism, or by the "religion of humanity" (Giner 1993:32; Wallace 1973:9). ${ }^{4}$ In short, Durkheim proposes a secular and universal view of social integration. Societies should aim for a higher ideal leading to more justice and the elimination of "external inequalities" ([1893]1964:409). The task of the most civilized societies is "a work of justice ... our ideal is to make social relations always more equitable, so as to assure the free development of all our socially useful forces" ([1893]1964:387).

4. For Durkheim's cosmopolitanism, see Cristi 2009, 2001; Inglis and Robertson 2008; Keohane 2008; Chernilo 2008; Turner 1990, 1992. 
During the early stages of his intellectual career, Durkheim did not conceive individualism as "a true social link" nor as a foundation of solidarity (Marske 1987:6; Tole 1993:21; Stedman Jones 2001:116). This stance was to change in later years, particularly during the Dreyfus Affair, the political scandal that divided France in the 1890s. By then, he had become convinced that moral individualism was the "only system of belief" that could guarantee the "moral unity" of France ([1898]1973:50). The growing emphasis on individual freedom neither weakened the social bond nor did it endanger the social order. It was only the amoral utilitarian individualism of the classical economists that threatened society.

At the height of the Affair, Ferdinand Brunetière, a literary critic, had written a piece lamenting that modern society was approaching anarchy "at a great pace." He characterized individualism as "the great sickness" of modern times where each individual becomes the "sovereign judge of everything," and admonished that when individualism "arrives at this degree of self-infatuation, there is ... nothing but anarchy" (in Cladis 1992:11). Durkheim responded by refuting Brunetière's claim that individualism would inevitably lead to moral anarchy. Individualism, he contends, does not always threaten the common good nor does it always lead to self-interest, although classical liberalism does both. Moral individualism far from being "anarchical," is moral and social. It is a belief system that ensures moral and intellectual unity, for it is humanity that is sacred and worthy of respect. The idea of the human person, as sacred and divine, is universal "unalterable and impersonal." Human beings "can love and honor [it] in common," for it stands "above the changing torrent of individual opinions" ([1898]1973:50, 52).

Defenders of Dreyfus had argued that he should be protected not only out of "sympathy" for another fellow man, but also for fear that if his rights were violated, in the future their rights could be violated as well. Durkheim took a slightly different position elevating Dreyfus' defense to a defense of the moral foundations of the Republic (Cladis 1992:24; see Farrell 1997). If the violation of Dreyfus' rights could not go uncontested "it is not out of sympathy for the victim; nor is it from fear of having to suffer similar injustices. Rather, it is because such attempts cannot remain unpunished without compromising the national existence" (Durkheim [1898]1973:53). To disavow the principles of justice and rights, is to "diminish" France and its people in the eyes of the international community, and commit "moral suicide" ([1898]1973:54).

Durkheim, Cladis notes (1992:135), provides an "elegant defense" of individual rights and human dignity. He is quite correct. Durkheim formulates a forceful theory of rights. What is controversial is not his 
theory of moral individualism per se. His concerns continue to have contemporary relevance. Durkheim is aware that the modern diversity of values, beliefs, and individual experiences defies the capacity of traditional religions to unite whole societies into moral communities (Cristi 2009:72). He believes that even the modern, atomic individual needs a common religion, and locates this common faith in the need for greater justice and sympathy for humanity. Durkheim came to see moral individualism not simply as a key feature of the process of modernization but as a new religion fulfilling the growing need for the core values of modernity - freedom, humanism, and egalitarianism. To this extent, one cannot but celebrate Durkheim's democratic, liberal, humanist concerns. He correctly anticipated the modern emphasis on rights: right to equal treatment, religious freedom, gay and lesbian rights, right to equal employment opportunities, etc. Needless to say, rights have expanded far beyond anything Durkheim ever envisioned. Furthermore, his theory remains a useful conceptual resource to investigate collective representations, symbolic processes, and belief systems in the modern world.

The controversy arises for two reasons. First, Durkheim's notion of moral individualism addresses only the social individual, i.e., man. He can thus be criticized for inconsistency and failure to articulate a truly universal approach to social justice and rights. Second, contemporary scholars dealing with his theory rarely explore it in relation to Durkheim's theoretical treatment of women. Hence, claims that Durkheim's sociology was a means of outlining "a practical programme of institutional reforms ... aimed at ensuring justice in social relations" (Cotterrell 2010:xii) imply a concern for social reforms and institutional arrangements that benefit both genders and ensure universal justice in social relations. This is not entirely correct. As we will see below, although Durkheim eventually came to recognize the need for "important" reforms regarding women's position in society, he still advises the "champions" of equal rights for women ([1897]1951:386) or "men of letters, men of law, and men of state" (in Pedersen 2001:246) against rapid and substantive reforms that would give the female sex legal equality and rights.

Feminists who criticize other aspects of his thought, are correct to note that Durkheim "never works" with a generic conceptualization of the human individual (Witz and Marshall 2004b:22). While Durkheim appears to be referring to all human beings, an examination of his views concerning the female sex clearly indicates that his universal call for the dignity, equality, and rights of the individual applies only to the male side of humanity. Thus, in theoretical terms the cult of the individual refers to the human person in general, but the respect and rights accorded to the individual are not equally distributed between the sexes (Cladis 
1992:71). Moreover, Durkheim postulates that justice in modern, industrial societies can be achieved by removing all "external" constraints (e.g., wealth inheritance and forced division of labour), and by guaranteeing just contracts, based on genuine reciprocity. Yet, his vision of a restructured social and economic order does not include a removal of external constraints for women nor does it guarantee just contracts for them.

Durkheim's ideas on women are scattered in almost all of his major works, but they reveal a clear picture of his understanding of women, and a well-developed theory of their place in society. However, as Lehmann (1994:33) is correct to note, his theory is "more latent than manifest" and has to be "reconstructed."

\section{Durkheim’s EARly Discourse on Women}

\section{Gender and Evolution}

Until quite recently, most male theorists did not question the belief that there was a "foundation in nature" for the relegation of women to the domestic realm, and for the "legal subjection of women to their husbands" (Okin 1979:200, in Kymlicka 2002:378). Durkheim's theory is no exception. Although his purpose was to give sociology a systematic scientific basis by providing social explanations of human behaviour, he often resorts to biological accounts to explain women's place in society, different rates of suicide of men and women, and the differential effects social institutions have on the sexes. Durkheim's discourse on women, as has been widely recognized, is based on "non-social" facts (Lemert 2006; Shope 1994; Sydie 1987; Wityak and Wallace 1981).

Several studies also indicate that, in classical sociological theory, gender differentiation and specialization of functions are explicitly explained as a key structural development of modernity - as "by-product" of social evolution (Witz and Marshall 2004b:20; Gerhard 2004:120; Shope 1994:24; Gane 1992:94; Lehmann 1990:164). Indeed, Durkheim assumes that sexual equality is an obsolete form of social organization. His theoretical architecture, especially his evolutionary model of the development of civilization, sees gender differentiation, and subordination of women to men, as indicators of progress (Lehmann 1995:576; Witz and Marshall 2004b:20).

In The Division of Labour, Durkheim observes that society has gone through different stages of structural transformations - from a lower primitive type held together by mechanical solidarity to a modern form based on organic solidarity. And, in his view, gender relations "faith- 
fully" represent the progress of civilization (Gane 1992:94). Primevally, men and women were anatomically indistinct, performed similar functions, and displayed the rudimentary social relations of mechanical solidarity. Durkheim notes that in primitive society, "the two sexes lead almost the same existence ... the woman mingles in political life," goes to war with men, and takes "a very active part" in it ([1893]1964:57). Thus, the primitive female was not "the weak creature" that she has become with the advancement of civilization. In fact, the most salient characteristic of the modern woman, "gentility," does not belong to her in the past. But "long ago, women retired from warfare and public affairs and consecrated their entire life to her family" ([1893]1964:58, 60).

Durkheim claims that the exclusion of women from warfare and public matters has been necessary for the general well-being of modern, complex societies. Where the sexes are relatively undifferentiated conjugal solidarity is weak, for sexual relationships are initiated and interrupted at will without any obligation linking spouses to one another ([1893]1964:59). The modern division of labour has been crucial in the evolution of marriage. The union of men and women has ceased to be "ephemeral," and has become an "intimate" and "indissoluble" association lasting the whole life span of the two partners ([1893]1964:59). Gender differentiation has also been beneficial in a more intimate way, for the "charm" and "mystery" of the relationship between men and women "would be difficult to maintain if [they] mingled their lives more completely" ([1897]1963:113-14). Likewise, Durkheim dismisses woman's power in matrilineal society by associating it with a primitive form of family organization. The "privileged" position of women, he argues, is not a "sure index of progress," but it is "caused by a still rudimentary domestic organization" ([1888]1978:213).

Durkheim reconsidered his conceptualization of primitive gender relations in later writings, most notably, in The Elementary Form where he describes nonegalitarian relations in primitive society, based on strict, gender-based taboos and interdictions. He now claims that primitive men possess a higher degree of religious majesty than women who, in relation to males, are perceived as profane, impure, and are prohibited from participation in collective totemic rituals and ceremonies (Di Cristina 2006; Witz and Marshall 2004b; Shope 1994; Gane 1992). However, as Shope has observed (1994:26), women not only participated in men's ritual but had their own ceremonial rites as well. Thus, women were not barred from ritual celebrations "but from Durkheim's analysis of ritual."

Durkheim's theoretical reformulation may be linked to his own intellectual shift from a structural stance, prevalent in his early writings, to an idealist orientation that emerged in later works where he emphasizes the 
significant role played by shared beliefs and collective representations (Marske 1987:1; Shope 1994:25). Initially, Durkheim explains women's inequality in terms of social structural arrangements. Patriarchy, for example, is for him the outcome of social evolution, specifically the modern division of labour. In later writings, however, he conceptualizes patriarchy as the result of "social morphology" not social structures (Shope 1994:25-6).

\section{Civilization and its Uneven Effect}

From Durkheim's viewpoint, the social development of women and men have not undergone a parallel development. Civilization has brought about a progressive differentiation between the sexes which favours the man. This inequality increases proportionately with civilization, so that in terms of intelligence and brain mass, "woman tends more and more to be differentiated from the male sex" ([1893]1964:57-8). Organically, the male sex has evolved while woman has retained the brain of primitive people. To support his argument, he quotes a scientist of his time, Dr. Lebon, who, in his view, was able to establish "directly" and with "mathematical precision" the original similarity of the two sexes in regard to the brain and the corresponding differences brought about by the progress of civilization ([1893]1964:57). ${ }^{5}$ This physical differentiation, in turn, has resulted in a progressive differentiation of social functions. As Lehmann points out (1995:576), in Durkheim's theory the male and female sex constitute two "distinct biological groups" and their biological difference is taken to be the "natural" basis of their specialized functions.

Durkheim argues that the division of labour has given a new meaning to the relations between the sexes which are now differentiated and based on the principle of interdependence and mutual need. Men take care of "intellectual" functions, women of "affective" ones. "One might say," Durkheim asserts, "that the two great functions of the psychic life are thus dissociated" ([1893]1964:60). This shift, Gane observes (1992:94), has produced "over millennia ... two quite different beings, mirrored in increasing dimorphism." Durkheim considers this to be an evolutionary achievement, for the moral effect of the division of labour has had beneficial ramifications for society. "If the sexes were not separated at all," the conjugal bond would not have had a chance to evolve ([1893]1964:61). The evolution of conjugal society gives us a "striking example of [this] phenomenon" ([1893]1964:56).

5. Some authors have speculated that Durkheim is referring to Gustave Le Bon, and that his "error" may have been deliberate (DiCristina 2006:215fn6). 
Durkheim's premise is that civilization has changed human nature. With the progress of morality man has become a "complex social being" ([1897]1951:216). He associates men with thought and intellectual activity, women with instincts. He thus argues that man has learned to make use of concepts and laws. His emotions and needs have become complex and diversified. But woman "has had less part in the movement of civilization. She participates less and derives less profit. She recalls ... certain characteristics of primitive natures" ([1893]1964:247). While man's aspirations and tastes have a social origin, and are tempered by the intellect, "his companion's are more directly influenced by her organism" ([1897]1951:385). The mental life of a woman is "less developed" and her sexual needs have "less of a mental character." Since she is more instinctive than man, she just needs to conform to her instincts to obtain "calmness and peace" ([1897]1951:272). Hence, woman "carries out her own nature," and a specialized role which is "very different from that of man" ([1893]1964:60).

Durkheim claims that "civilization has made man what he is ... man is man only because he is civilized" ([1914]1973:149). As Gane states correctly, however, "civilization" in Durkheim's work "is a male possession." And his conviction of an "unequal distribution" of civilization led him to perceive women as weak, "outsider" creatures governed by instincts which, in turn, led him to the belief that women's social status reflected their "true nature" (Gane 1992:87). This view has been echoed by Lemert (2006:127) and Shope (1994:25), among others, who argue that Durkheim theorizes women as natural, "asocial" creatures determined by biology. Woman, thus, depends upon her nature, man upon society (Lehmann 1994; Sydie 1987).

Witz and Marshall (2004b:20-21) are correct to point out that, although classical sociologists started out with the conception of "the individual as social," they never conceptualized both sexes as "wholly social in their constitution." Rather, they constructed a theory of gender differences and relations rooted in the nature versus the social antinomy. Their failure to "think beyond [a] gendered dualism," the authors note, explains why women were "metaphysically" excluded from the social, and "institutionally" excluded from society. In other words, since "society" was defined in terms of male activities and concerns, or used as a "code word" for their interest, benefit, and needs, women were of necessity conceived as marginal or outside social life (Pedersen 2001:232; Sydie 1987:46).

Not surprisingly, Durkheim conceives women as less civilized relative to men. He suggests that women possess the social nature of primitive man which "demands very little" ([1897]1951:215). Her social life 
is uncomplicated, and very "simple social forms" satisfy all her needs. She has less "sociability" and her sensibility is quite vestigial and undeveloped ([1897]1951:215). Durkheim draws a comparison between a woman's social nature and that of children, old people, and animals. Society, he tells us, is "lacking" in her and children, and "retreats" among the aged, or they "retreat" from it. They all feel less "the lack of what is necessary for living."And then he adds, the "immunity of an animal has the same causes" ([1897]1951:215). This explains different rates of suicide of men and women or why suicide among children is rare and decreases in old age. ${ }^{6}$ Simply put, woman has remained closer to nature, is more primitive than man, and, as a result, has been rendered, if not incapable, at least less capable of social development.

Durkheim maintains that man can "escape nature only by creating another world.... That world is society" ([1893]1964:387). Woman cannot escape her condition. Being outside social life, she is neither allowed to create society nor to participate in the social world created by man. Or, as Witz and Marshall (2004a:6) point out, to the extent that only men are conceived as the rational individual who embodies the social, they alone can avoid "the demands of nature."

Having advanced the idea that civilization has arrested woman's development, Durkheim explains her subordination in natural terms. "By constitution, woman is predisposed to lead a life different from man" ([1893]1964:264). ${ }^{7}$ The two sexes do not partake equally in social life. Man participates actively in society, but woman "lives outside of community existence" ([1897]1951:215). She just looks "from a distance" ([1897]1951:385). This means, as Gane has remarked, that right at the heart of the modern world we find

a very specific mechanical caste whose character seems precisely to be transmitted by heredity, and which has fixed psychological faculties which disable it from participating in the movement of civilization, although it is civilization which also appears to have created the disability. (Gane 1992:105)

At this stage of his intellectual career, Durkheim seems convinced that inequalities between men and women express "natural" inequalities, rather than external factors in woman's social conditions, such as lack

6. Durkheim ([1897]1951:341) uses a similar argument to explain women's lower rates of homicides. They "do not participate in collective life in the same way," women "merely" lack opportunities. But he suggests that women have a "monopoly" of murders whenever they are within their scope (poisonings, abortions, infanticides).

7. Lukes (1973:17-8) writes that Durkheim was "always equivocal" about the role of biological influences. For "pre-social, organically given factors play a crucial role at various points in his theory, as for example, in his doctrine about the biologically given characteristics of womanhood." See also Wityak and Wallace 1981; Sydie 1987. 
of opportunities, and different education and socialization experiences. This may explain why he does not hold a generic conception of the human individual and why women are not included in his vision of equity and justice. He "is clear that men and women are naturally differentiated, and on the basis of this, differentially incorporated into [social life]" (Witz and Marshall 2004b:22; Lehman 1995). With women excluded from the social, only the male "individual" is the recipient of the rights and freedoms he promotes and advocates.

\section{Gender, Marriage, Divorce, and Suicide}

In Suicide, Durkheim notes that this fundamental difference between the sexes constitutes the primary reason why marriage cannot simultaneously be "agreeable" to man and woman, "one of whom is almost entirely the product of society, while the other has remained to a far greater extent the product of nature" ([1897]1951:385). He observes that marriage imposes serious restraints on women without any great advantages. He refers to the "depressing influence [for women] of the matrimonial yoke," or the "unfortunate" and "ill" effects of marriage, a "profitless yoke," on wives ([1897]1951:190, 193, 274). It follows that marriage has a preservative effect against suicide, but it is "very limited." While it benefits husbands, it has a detrimental effect on women. Yet, Durkheim points out, where divorce is easier to obtain or widespread, the "immunity" of the married woman is stronger - the rate of suicide decreases for wives ([1897]1951:269). He admits that this dilemma may be solved when the difference between spouses becomes less pronounced, when marriage no longer privileges one spouse to the disadvantage of the other ([1897]1951:386).

Durkheim's observation about the negative effect of marriage, and its lack of preservative effect for the female sex, reveals a profound sociological insight, but he ignores the implications of his findings. ${ }^{8} \mathrm{He}$ notes that marriage, like religion, is an effective antidote against suicide ([1897]1951:198). Likewise, his data indicate that divorce rather than being deleterious to the wife, protects her against suicide, for the "more often and easily the conjugal bond is broken, the more the wife is favored in comparison with the husband" ([1897]1951:266). ${ }^{9}$ But nearly a dec-

8. In Tiryakian's view (1981:1025,1031), Durkheim's findings were too “anomalous" and threatening to be incorporated into his theory. He "could not face up to the implication if not contradiction of his analysis." See also Lehmann 1994:65.

9. Almost a decade later Durkheim retracts his position that divorce increases the immunity of the wives by affirming that divorce does not affect "feminine suicide in an appreciable way." He also changes his position on the detrimental effects marriage has on women. Because "she benefits from it only a little, she suffers by it only a little" ([1906]1978:246, 247). 
ade later he asserts that the legalization of divorce would have serious consequences, without increasing the happiness of the "average" spouse or diminishing their sufferings ([1906]1978:250). His contention is that family life cannot be transformed into mere cohabitation where each partner has their own area of "interest and concerns," and where each has the right to part ways if they so desire ([1907]1980a:288). Durkheim opposes, specifically, divorce by mutual consent.

In his article "Divorce by Mutual Consent," Durkheim writes: "I do not feel I am a reactionary," and acknowledges that even the "most sacred" institutions are not "above question." He also recognizes that conceptions of the family are evolving. However, in his view, this is "no reason to yield to the whims for change which arise overnight" ([1906]1978:241). If divorce by consent is legalized, it would have a dangerous effect on the institution of marriage and "its normal functioning" and would create a grave social problem "whose repercussions the individual would bear."10 It would constitute, in fact, a far greater evil than the "individual evils" it is supposed to alleviate ([1906]1978:241). Durkheim, in short, ignores how the females fare with marriage and generalizes "in terms of how the male half would fare" with its deregulation (Tiryakian 1981:1031). It is baffling, Tiryakian reflects, why, given his "astute" sociological insight, Durkheim insists in speaking of "conjugal anomy" when his data clearly indicate that the liberalization of marriage "is not that injurious to the health of half the sexual partners" (1981:1029).

In Durkheim's view, conjugal anomie poses a serious social menace. If it is to be attenuated only one solution is possible — "to make marriage more indissoluble." Durkheim recognizes that this would create a "disturbing" problem - the suicide of husbands would diminish but those of the wives would increase. He raises the question as to whether one of the sexes should be "sacrificed," and his answer is that "nothing else seems possible as long as the interests of husband and wife in marriage are so obviously opposed." Man needs sexual regulation or "discipline," which marriage provides, woman needs "liberty" which marriage denies ([1897]1951:384).

\section{Women in Modern Society}

\section{Social Integration and Functions}

Durkheim concedes that the antagonism of the sexes, which makes the solution "impossible," may disappear in the future. Still, he remains convinced that women will never be able to fulfill the same functions in

10. Here he refers to the "individual" in gender-neutral terms, but a few pages later he recognizes that "the preceding facts apply solely to men" ([1906]1978:245). 
society as man. In the future woman may play a more important role in society, but it will always be peculiar to her own sex. The sexes may become more "socially equalized, but in different ways." He predicts that gender differences will become increasingly more pronounced, and will be "of greater social use than in the past" ([1897]1951:385). He thus objects to those who believe that the sexes are becoming more similar. Males and females, he tells us, may in the future "approximate each other by their very differences" ([1897]1951:385). As Lemert points out, Durkheim suggests that gender differences may be transcended by functional equivalence. Woman takes care of aesthetic and affective functions, man of instrumental ones. "She makes the home and other things beautiful; he works and makes the world" (Lemert 2006:127).

Still, Durkheim is open to the possibility that, in the future, women will participate more in the larger social world. They will be neither "officially excluded from certain functions [nor] relegated to others." But this apparently progressive view is qualified in two ways. First, while woman may be able to choose "more freely," her choice will be decided by her "aptitudes." Due to the differentiated evolution of the sexes, he expects that women will likely select the "same sort of occupations." This means that female functions will be rather similar, though they will not be "obligatory" ([1897]1951:385fn16). Second, women may take up occupations previously held by men, either because men "permit" it or because they have to relinquish them to devote themselves to higher pursuits. Women, in fact, may take up artistic functions because "man, more and more absorbed by functions of utility, has to renounce them" ([1897]1951:385). Thus, if women are participating more in the literary sphere of life, if arts and literature are becoming "feminine tasks," this is due to a new and modern kind of "differentiation." The male sex "seems to permit it in order to give itself more specially to the pursuit of science" ([1893]1964:60).

To argue that women may take up certain functions insofar as men renounce them, is to suggest that women's integration into modern society is dependent on the benevolence of men or to the degree that men allow it. Worse yet, his endorsement for women's social integration seems prompted by the "interests of men and "society" rather than those of women (Lehmann 1995:578). Durkheim attributes a higher dignity to intellectual activity, and suggests that the moral-aesthetic sphere of life is inferior, somehow inessential, and certainly of secondary importance when compared to science. ${ }^{11}$ So even this concession would not signifi-

11. In the introduction of the first edition of The Division of Labour ([1893]1964:431 fn21) Durkheim argues that the artistic or aesthetic domain is inferior, as it is essentially a sphere without duty or obligations, based on the independent creativity of the individual. 
cantly improve women's unequal social position. While women may become more active in society, they will still be taking up social functions that are less prestigious and hold less power than men's (Di Cristina 2006:226; Pederson 2001:249; Gane; 1992:119).

Di Cristina (2006:227) offers an alternative, yet debatable, interpretation. He does not deny that the affective sphere of life seems, occasionally, of secondary importance to Durkheim. Nor does he deny that by associating women with arts and letters, he appears to support a division of labour that clusters women in positions of lesser social value. However, he suggests that Durkheim's distinction between arts and sciences is not always as consistent as others have claimed. On the one hand, Durkheim himself suggests that no "great divide" exists between them. On the other hand, the artistic sphere of life is perceived by him as the realm of "freedom." This may suggest, Di Cristina argues, that the moral aesthetic sphere, by offering greater freedom to individuals, is "preferable" to intellectual functions. Given the constraints imposed by science, the possibility exists that, in the long haul, "many women could secure significantly more freedom than many men" (2006:227). What is more, he also contends (2006:224) that both conservative and "potentially feminist elements" can be found on Durkheim's views on gender. Surely, Di Cristina's position can be debated, but it is beyond the scope of this paper to engage in such debate.

The important point here is that Durkheim holds a gendered conception of social equality and justice which is exclusive of the female sex. By conceiving women as essentially different in relation to men, he assumes that they should have differentiated rights, both in the public and private spheres of life. Moreover, he considers that granting equal rights to both genders is not good for the health of society. In The Division of Labour he points out that the family has played an essential role in the "moral history" of humankind. It is the "place par excellence of morality" ([1893]1964:16, 15). Later, in 1904, he insists that the family is the sphere par excellence of "feminine activity," and claims that it cannot stand firm "without a resulting legal subordination of the wife to her husband." Durkheim considers this subordination a "necessary condition of family unity" ([1904]1980:209). In 1907, he revisits the issue in his review of a book by Marianne Weber, where he claims that legal equality would have a deleterious effect. It would compromise the "organic unity" of the family and weaken the matrimonial bond ([1907]1980a:288). In another review, written the same year, he reiterates that women's inferior position in the family is required "only insofar as [it] is needed for good conjugal discipline and the shared interests of the household" ([1907]1980b:218). Hence, from Durkheim's perspective, there can be 
no equity in conjugal society. It follows that there can be no justice in social relations if males are given unfair legal and social advantages.

Durkheim agrees with Weber's thesis that domestic evolution has determined the evolution of women's right, and that her place in the family has determined her position in society. This represents, for him, an "undeniable" principle ([1907]1980a:286). However, he finds Weber's conception of family history "simplistic" to the point of concealing how difficult it is to analyze or even solve the problem. Yet, he does not reject Weber's contention that the conditions of wives have grown "increasingly worse," since the establishment of the wife's civil incompetence ([1904]1980:209), or that the "sovereignty of men" has been maintained "by the force of prejudices," resulting in "everlasting subordination." Neither does he dispute her claim that while in modern society patriarchal power "is no longer justified," women are still treated as "inferior" and precluded from "freely developing" their individuality both "inside the home [and] in public life" ([1907]1980a:287). Even so, he insists that the moral importance of the wife's role has increased to the degree that the conjugal society has become more patriarchal and strongly organized.

Though Durkheim accepts Weber's premise that the patriarchal regime is responsible for woman's legal status as a minor, he challenges her idea that patriarchy has meant "women's complete subservience" and the source of women's oppression. This, he argues, is "wide open to question" ([1907]1980a:288). Instead, he claims that the origins of woman's rise to higher status can be found in forms of patriarchal familial organization insofar as the woman's role, "which is precisely to preside over the life indoors," assumes more importance and the moral status of the wife/mother also increases ([1907]1980a:288). Durkheim claims that as the family institution has evolved, the spouses have become "closer," more "in touch," for the husband is no longer drawn away from home as much as in former times. The more the "man's mind" is absorbed with family issues, or the more he is drawn into the ordered, hierarchical unity of the family, the more the wife benefits for he is less likely to see her as inferior ([1907]1980a:288). Simply put, woman's social position is determined by her "status in the family and by the status of the family in society” (Lehmann 1994:56).

He uses the Roman family as a model of patriarchal power at its zenith. In Rome, "the wife is respected by those around her. She shares her husband's position" ([1907]1980a:288). Patriarchy advances the interests of women by advancing the interests of the family; assuming thus, that women's interests are in perfect harmony with the interests of the family. Durkheim further elaborates that, if feelings of respect for women have become more intensified with the progress of civiliza- 
tion, this is due to "the religious respect inspired by hearth and home" ([1907]1980a:288).

Durkheim's rejection of gender equality appears to have been grounded on a fear of the disruptive effect it could have on the institution of marriage. His fundamental concern is a radical transformation of the family. It is worth noting that on personal family matters, Durkheim held a very "puritanical disposition." ${ }^{2} \mathrm{He}$ opposed his daughter's desire to pursue a university career. He wanted the modern family guided by a "rigid moral code" which, in terms of sexual morals, was similar to that of the Catholic and Protestant religions. In addition, he was alarmed by the rising rates of illegitimacy and divorce in France (Pickering 2002:14). Not surprisingly, he took the position that women's emancipation would affect marital solidarity and, ultimately, have deleterious consequences on society as a whole. In Suicide, he admonishes defenders of equal rights for women that they "forget that the work of centuries cannot be instantly abolished," that legal equality cannot be legitimate as long as the "psychological" inequality between men and women is so "flagrant. Our efforts must be bent to reduce the latter." To be equal in front of the law, and equally protected by the institution of marriage, they must be first of all "creatures of the same nature" ([1897]1951:386). In his earlier writings, in short, he took the position that due to woman's psychological and social backwardness, equality could not be granted at that particular historical juncture.

\section{"Intermediary" Period of Transition}

For Durkheim, the "woman question" appears to have been a vexing and difficult to solve issue. By the early 20th century, his stance on women slightly changes. He now seems to take a somewhat different attitude toward them. Biologically given factors, common in his earlier writings - such as woman's natural predispositions, primitive nature, or lack of intelligence - no longer dominate his discourse. ${ }^{13}$ Durkheim seems to accept, albeit not consistently, that woman's differences cannot simply be attributed to her primitive nature or psychological inadequacy, that her position in society is socially determined and based on socially prescribed obligations. Nonetheless, he does not recant his

12. Durkheim's "domestic ideal" is most clearly illustrated by his own personal life. In the words of his nephew M. Mauss, Durkheim's wife "created for him the respectable and quiet familial existence which he considered the best guarantee of morality and of life" (in Lukes 1973:99; see also Pedersen 2001:241).

13. As suggested earlier, this may not be simply a matter of a tentative liberalization of his views, but rather a reflection of his own shift away from an emphasis on the evolution of differentiated social structures and functions, towards moral forces and collective representations. 
conservative posture on women. In 1900, he advises women to "seek for equality in the functions which are commensurate with her nature" ([1900]1980:296). And four years later he insists that the subordination of the wife is inevitable at that "given moment in history." The problem is no longer woman's nature, but the institution of the family. Legal individuality, he concedes, may come at a later date, but this will require a "well-cultivated" family organization. "We are still in the process of seeking it out" ([1904]1980:209).

As late as 1907 Durkheim is still insisting that whatever weakens "the organic unity of the family and of marriage" inevitably cuts off the very "source" of women's "higher status" ([1907]1980a:288). Women should consider that, if they want to play a larger role in civil society, their stature will be "diminished" because the gains obtained with the attainment of civil rights, "will be offset by important losses" ([1907]1980a:288-89). That is, woman's moral status - the feelings of respect that she enjoys as mother and wife - will suffer. Paradoxically, at around the same time period, Durkheim writes in Professional Ethics and Civic Morals: "the progress of justice is measured by the degree of respect accorded to the rights of individuals, because to be just is to grant everyone what he has the right to demand" (in Giddens 1986:49). ${ }^{14}$ Apparently, from Durkheim's perspective, social evolution had not reached that point where justice could be universally (equally) distributed between males and females.

He recognizes that European civil law is in need of reform ([1907]1980a:288), but he worries about redressing gender inequality in too much haste. He admits that equality between men and women "will be achieved only if the woman blends herself" more into public life. But then he ponders "how will the family be transformed?" ([1901]1980:305). Feminist demands may produce moral chaos instead of beneficial social change. He thus suggests that the only effective remedy lies in a gradual transformation of social organization, and a gradual liberation of women from the shackles of tradition (Ramp 2001:100; Di Cristina 2006:229). This is in line with his view that while a social arrangement may be outdated, it is "wise to retain it provisionally" and "better to replace it prudently and gradually" (Durkheim [1909]1979:76). Durkheim uses feudalism as an example. He points out that, at a particular period in history, feudalism was a rational way to organize medieval society, "just as it was to lose that rationality later." But in between these two phases, there was

14. Professional Ethics, published posthumously, is a collection of a series of lectures Durkheim delivered at Bordeaux between 1890 and 1900, and at the Sorbonne in 1904 and 1912. The section "The State," from where this quote is taken, dates from between 1900-1905. 
an "intermediary period when it was wise to retain it provisionally, while at the same time preparing for its evolution" ([1909]1979:76).

It would appear that Durkheim accepted that gender relations and women's rights were outdated. But he remains convinced that they are in a stage of evolution, in an "intermediary" period of transition without yet being stabilized in a new form. Thus, from his point of view, it seems wise to retain gender inequality and deny women legal equality and rights, "provisionally," while at the same time preparing "gradually" and "prudentially" for the changes to come. This view led him to characterize feminism as an "unconscious" movement, suggesting that feminism does not take into account the potential social repercussions of its demands. Feminism "deceives itself" by formulating demands that cannot yet be achieved. To be sure, he is doubtful about the concrete details of the feminist movement, but he recognizes that it is not just a passing fancy ([1900]1980:296).

\section{Gendered Construction of Justice and Rights}

This is not to deny that Durkheim advocates rights, equality, dignity of the individual, and that he longs for a just society. Nor is it to deny that the personal freedom of the modern individual is, for him, a central characteristic of modernity (Lukes 1973:23). As mentioned above, there is no fundamental problem with his abstract conception of moral individualism. The problem is that Durkheim's universalistic moral theory is at odds with his particularistic moral practice, especially with respect to the woman question. What lies at the base of individual rights is not the notion of the gendered individual, but of humankind in general. Durkheim's preoccupation with justice and rights, however, does not address the whole of humanity. Simply put, his sociology of women clashes with his Kantian philosophy on human rights. Though his discourse appears universal, his yearning for justice and freedom entails neither an equitable relationship between the sexes nor universally defined rights.

Needless to say, Durkheim's theoretical contradictions point beyond him to a larger set of issues affecting classical discourse about the "social," the "individual," "natural," "universal." Written from a male standpoint, discussions about the "individual" always take as the starting point men and a gendered construction of the social (Smith 1987:91). ${ }^{15}$ Feminist critics, like Carole Pateman (1988), have rejected the universalism of Western political thought as false and formal rather than sub-

15. For studies from the standpoint of women, see D. Smith 1987, 1992; S. Harding 1991; Witz and Marshall 2004a; Sydie 2004. 
stantive. Historically, universal ideals have been limited to white males - they alone have been the autonomous, self-governing individual with rights and liberties. Under the umbrella of universalism all sorts of prejudices, stereotypes, discrimination, as well as gender, racial, and class privileges, have been conveniently concealed.

Durkheim maintains that the task of civilized society (where moral individualism is at its highest point) is "a work of justice" ([1893]1964:387), and claims that organic solidarity makes social regulations more equitable so as to assure the freedom of all individuals and "the free development of all our socially useful forces." He also states that the modern individual has come "to acquire even wider rights over his own person and ... possessions" ([1950]1992:56), and that social justice is essential to achieve, guarantee, and maintain social solidarity. Such statements are incompatible with his views on women, and for the female sex they are empty words, admittedly, hard to swallow. Modern society cannot ensure harmonious gender relationships if women are deprived of their autonomy, freedom, and civil and political rights.

Durkheim's theory of women reflects a "quintessentially male discourse" (Witz and Marshall 2004a:1) that directly contradicts his own statements concerning individual freedoms and rights. Contemporary scholarship on moral individualism, however, shows the pervasive tendency to ignore this obvious but often overlooked fact. Authors address Durkheim's yearning for social justice, and his commitment to liberal values and the "free individual," in generic, universal, and abstract terms. We are told, for example, that Durkheim's sociology reveals a profound desire "to expand the realm of human freedom" (Prager 1981:919), or that the individual who embodies the ideals of moral individualism is “"man' in general" (Giddens 1972:9). Others have pointed out that Durkheim's calls for equality and justice are "moral imperatives" necessary for "the self-fulfillment and welfare of every citizen" (Marske 1987:11, emphasis added). Cladis, whose writings show complete awareness of Durkheim's exclusion of women, describes him as a radical social critic who "went to the root of many problems" of modernity. Durkheim, he notes, equipped with the "sensibilities" of a historian, "reformed inherited traditions" uncovered "prejudices," and was not tied to "the status quo." This "helped him to envision wholesome social change" (1992:226-27). Still others claim that Durkheim maintains in his writings "a complex balance between the justice of equal opportunity and the justice of equal treatment" (Cotterrell 2010:xxii). None of these remarks make sense in the context of Durkheim's theoretical ideas of women and their place in society. However, they are significant for they illustrate a "gendered blind spot" which is deeply rooted in classical sociology 
and, to a certain extent, has been "inherited" by contemporary scholars (Pederson 2001:256). Admittedly, few sociologists today would suggest that Durkheim can be taken up without a reconstruction of his work, i.e., without taking into account the limits of his understanding of sex and gender. Yet, the tendency to use a gender neutral language and ignore that his theory is exclusive of women, persists. That is, the blind spot tends to reappear within present-day scholars' own writings.

Though Durkheim uses terms such as "rights," "social justice," "man," "individual" generically, it is clear that for him the male individual is "the masterpiece" of civilization ([1897]1951:213) and the carrier of rights. Only man is social and civilized. The woman is a lesser social being. As previously indicated, together with the child and the aged she is placed "outside social life," and outside Durkheim's society. Some have even argued outside Durkheim's "sociology" (Lemert 2006:127; Pedersen 2001:248; Sydie 1987:46). ${ }^{16}$ In his theoretical model women remain at the margins of society, are ascriptively confined to family life, and are not given the autonomy and civil rights bestowed upon male social beings. This may explain why he pays scant attention to the role repressive social forces have played in producing such unequal gender relationships. Given his commitment to social justice and economic rights, it might be thought reasonable to think that he would have wanted to eradicate all kinds of inequalities. Instead, he adopted a "highly paternalistic, even reactionary stance," and was "theoretically predisposed" to take a conservative position regarding women's unequal status in society (Gane 1983:227).

The common objection to this line of argument is that we cannot judge social scientists by the standards of today for their theories simply reflect the epoch in which they lived. ${ }^{17}$ To be sure, when Durkheim lived and wrote, patriarchy, racism, and sexism were prevailing views, so he was, undoubtedly, influenced by traditional ways of thinking about

16. This is well-illustrated in recent publications. Several renowned books on Durkheim's work, such as Stedman Jones (2001), W.S.F. Pickering and H. Martin (1994), Meštrović (1992), do not include in their index a subheading for "female," "women," "gender relations" and so on. Pearce's book, The Radical Durkheim (2001), does have a subheading for "women, circulation, in primitive societies" which refers the reader to Lévi-Strauss, not Durkheim. Durkheim's theoretical treatment of women is thus completely overlooked and silenced in these works.

17. Some scholars suggest that if Durkheim's ideas are placed in the context of his time they do not fit neatly into an antifeminist framework, and can even be said to parallel or support the family-centred "familial feminism" of late 19th century France (Di Cristina 2006; Offen 1984). This view has been amply contradicted by feminist scholarship which locates Durkheim's ideas on women at the centre of an ultraconservative and antifeminist ideology, not simply in the light of today's standards, but in relation to the historical context and feminist challenges of his own time (see Pedersen 2001; Gane 1992; Lehmann 1994, 1995; Wityak and Wallace 1981 to name a few). 
gender (Lehmann 1994:5-6; Ermirbayer 2003:23). ${ }^{18}$ But "with rare exceptions," as Gane has pointed out (1992:88), sociologists have tended to regard his view on women as a "minor blemish" or a flimsy expression of "a dominant ideology and mistaken biology." Tiryakian (1981:1026), for example, describes Durkheim's position as merely reflecting the "prejudices" and male-centred mentality of his time. But it may be argued that Durkheim was not just "influenced" by hegemonic ways of thinking, or that his work did not merely "reflect" the spirit of his time. Rather, he developed a theory which explains and justifies the subordination of women to men, and women's unequal position in society.

Moreover, long before Durkheim was born, the woman question had become part of the French public debate. To be sure, women were subordinated and relegated to a secondary position in society, but they were not silenced by men. By the late 1790 s, women were actively participating in political clubs, and several women's groups were created in an attempt to improve the situation of women in France. ${ }^{19}$ Durkheim's contemporaries, Jenny P. Hericourt (1869) and Hubertine Auclert (1878) publicly expressed their concerns regarding gender injustices. Hericourt complained that rights were defended when "the individual is a man," and ceased to be recognized "because the individual is a woman." Auclert denounced that the right to vote which entitled men to exclude millions of women could not "bear the name universal" (in Lehmann 1994:22). During the late 19th and early 20th centuries women's movements were emerging not only in France but throughout the Western world as a response to the refusal of politicians to settle the problem of women's civil and political rights (Landes 1988:169). In France, the so-called woman question had become politicized and was very much part of the public discourse of monarchists, republicans, and socialists. Socialists and feminists called for radical reforms and were vociferous in their desire to change the Napoleonic Code which excluded females from the definition of citizenship, despite recognizing "the equal rights of all citizens" (Landes 1988:170; Hinson 1994:23, 28). Finally, Durkheim's own writings clearly indicate that he was aware of feminists' demands and of other more progressive views on women's place in society.

18. It may be argued, however, that thinkers writing long before Durkheim, such as Marx, Engels, J.S. Mill, Fourier, Saint-Simon, were aware of, and denounced in their writings the injustices suffered by women in society. Their solutions may be disputed today but still they called for more equitable gender relationships.

19. Olympe de Gouges, who founded the first women's society during the French Revolution, called for equal legal and social rights for women (Landes 1988:124). Likewise, the philosopher Condorcet spoke on behalf of women's rights: "either no individual of the human species has any true rights, or all have the same. And he or she who votes against the rights of another, of whatever religion, colour, or sex, has thereby abjured his own" (in Landes 1988:114). 
I am far from disputing the fact that Durkheim developed his theory within the context of justice and freedom, as defined by most males of his time. He was certainly not alone in upholding traditional gender roles. But to place Durkheim's thought in the social and intellectual context of his time, also means taking into consideration the progressive voices of dissent. Outspoken proponents of women's rights, including some politicians and social thinkers, advocated alternative conceptions of justice and attempted to challenge the status quo. Durkheim, by contrast, "caught up in [a] reactionary ideology ... appears as a Cicero or Bonald trying to halt the inevitable forces of progress" by clinging to outmoded forms of social organization (Gane 1992:89). ${ }^{20}$

\section{Conclusion}

This study places Durkheim's theory of individualism, rights, and social justice in the context of his views on women, and offers a critique both of his theory and its present-day interpretation. Central to his theory is the belief that individualism, as it evolves, brings to light new moral inclinations and a "greater thirst for justice." Durkheim claims that modern individuals now perceive as "unjust" and as "contrary to human dignity" social relations that in the past "did not seem unjust at all" ([1903]1961:12).

Yet, his approach to a just social order is essentially formulated around the male individual. The inequality suffered by females is not part his "project of modernity" (Llobera 2002:77). When Durkheim's "individual" is conceptualized as a woman, his theoretical inconsistencies become all too evident. In The Division of Labour, he condemns the consequences of inheritance and birth privileges ([1893]1964:384), but fails to acknowledge that women, too, are born into and inherit a legacy of inequality, discrimination, and oppression. While claiming that no individual should be given advantage because of birth rights, in his theoretical model the male sex has privileges because he is born a man. Males have social superiority and unjust advantages with respect to the market, the law, and the family, advantages which, to use his own words, have little to do "with their personal worth." Furthermore, he claims that a growing sense of justice characterizes modern society. But even at the

20. Durkheim's position on class inequality is strikingly different. Suicide and Professional Ethics and Civic morals, are "political attacks" on utilitarian economic liberalism (Turner 2006:137) which he perceives as a serious threat to equality and social justice. In The Division of Labour he denounces the exploitation of workers and calls for practical reforms to alleviate economic inequality. His call for the elimination of inheritance and birth privileges, even by today standards, is quite bold and progressive. 
turn of the 20th century, he considers women's inequality to be neither unreasonable nor absurd, but necessary for the health of society and for the moral organization of the institution of the family. Clearly, in Durkheim's theory males and females do not confront the same social reality, nor are they equally entitled to the same freedoms and rights. For him, as we have seen, the "individual," is the social human being. Or, as Ramp has aptly remarked, "individuality" in Durkheim's theory, begins with "patriarchy and ends with a universalist liberal humanism which suppresses the fact that it is still gender exclusive: humanity, for Durkheim is 'all men"' (2001:99).

Cladis (1992:289) makes the claim that Durkheim "had little in common with those we normally call conservatives or reactionaries." This is only partially true. To argue this, is to ignore Durkheim's views on women. In this respect he is both a reactionary and arch-conservative thinker. He clearly takes a conservative approach to gender inequality, suggesting that if reforms are to be made they must come gradually after proper consideration of historical antecedents and potential consequences. To be sure, he is not a conservative in the tradition of Burke, Maistre, or Bonald. ${ }^{21}$ Durkheim was a defender of liberal values. Still, given his response to the woman's question, his call for human rights and social justice is hardly compatible with his unwillingness to envision a social order without some kind of women's subordination and violation of their rights and civil liberties. In his theoretical model, justice and rights are bestowed differentially, depending on whether the "individual" is male or female. He advocates protecting the individual's (men's) right to participate freely in social life, but shows little urgency in ensuring that life, for women, be governed by the same moral standards. In the final analysis, Durkheim betrays his own liberal principles and commitment to social justice.

Ironically, Durkheim insists that the "individualist who defends the rights of the individual defends at the same time the vital interests of society, for he prevents the criminal impoverishment of the last reserve of collective ideas and feelings which is the very soul of the nation" ([1898]1973:54). Disavowing his own words, he neither defends the rights of women nor does he show any pressing need to redress their unjust situation in society. He supports the status quo and allows traditional morality to go unchallenged.

21. Yet, he shares with them the idea that anything that undermines the patriarchal family is disruptive of the social order. In fact, the argument proposed by Durkheim against divorce by mutual consent, is very similar to the one used a century earlier by the "great reactionary" Bonald (Tiryakian 1981:1030). 


\section{REFERENCES}

Barmaki, Reza. 2008. The relationship between justice and freedom in Emile Durkheim's thought. International Journal of Criminology and Sociological Theory 1(1):51-61.

Beckford, A. James. 1989. Religion and Advanced Industrial Society. London: Unwin Hyman.

Bellah, N. Robert, ed. 1973. Emile Durkheim on Morality and Society. Chicago: University of Chicago Press.

Besnard, Philippe. 1973. Durkheim et les femmes ou le suicide inachevé. Review française de sociologie 14:27-61.

Chernilo, Daniel. 2008. Classical sociology and the nation-state: A re-interpretation. Classical Journal of Sociology 8(1):27-43.

Cladis, S. Mark. 1992. A Communitarian Defense of Liberalism: Emile Durkheim and Contemporary Social Theory. California: Stanford University Press.

Coser, Lewis A. 1960. Durkheim's conservatism and its implications for his sociological theory. Pp. 211-232 in Kurt H. Wolff, ed., Emile Durkheim, 1858-1917. Columbus: Ohio State University Press.

Cotterrell, Roger. 2010. Durkheim on justice, morals and politics. Pp .xi-xxiv in Roger Cotterrell, ed., Emile Durkheim: Justice, Morality and Politics. Farnham: Ashgate Publishing.

Cristi, Marcela. 2001. From Civil to Political Religion: The Intersection of Culture, Religion and Politics. Waterloo: Wilfrid Laurier University Press. 2009. Durkheim's political sociology: Civil religion, nationalism and globalisation. Pp. 47-78 in Annika Hvithamar, Margrit Warburg, and Brian Arly Jacobsen, eds., Holy Nations and Global Identities. Leiden: Brill Publishers.

Di Cristina, Bruce. 2006. Durkheim's latent theory of gender and homicide. British Journal of Criminology 46:212-233.

Durkheim, Emile. [1888] 1978. Introduction to the sociology of the family. Pp. 205-28 in Mark Traugott, ed. and trans. Emile Durkheim on Institutional Analysis. Chicago: The University of Chicago Press.

- [1893] 1964. The Division of Labour in Society, translated by George Simpson. New York: Free Press.

[1897] 1951. Suicide: A Study in Sociology, translated by John A. Spaulding and George Simpson. New York: New York Free Press. [1897]1963. Incest: The Nature and Origins of the Taboo, translated by Edward Sagarin. New York: Lyle Stuart, Inc. [1898] 1973. Individualism and the intellectuals. Pp. 43-57 in Robert N. Bellah, ed., Emile Durkheim: On Morality and Society. Chicago: University of Chicago Press. 
[1900] 1980. Review. Anna Lampérière, Le rôle de la femme, devoirs, droits, éducation. P. 296 in Y. Nandam, ed., Emile Durkheim: Contributions to L'Année Sociologique. New York: The Free Press.

- [1901] 1980. Review. Jacques Lourbert. Le problème de sexes. Pp. 304-305 in Y. Nandam, ed., Emile Durkheim: Contributions to L'Année Sociologique. New York: The Free Press.

- [1903] 1961. Moral Education: A Study in the Theory and Application of the Sociology of Education, edited by Everett K. Wilson. New York: The Free Press.

[1904] 1980. Review. Ernest D. Glasson, Histoire de droit et des institutions de la France. Pp. 207-210 in Y. Nandam, ed., Emile Durkheim: Contributions to L'Année Sociologique. New York: The Free Press.

[1906] 1953a. The determination of moral facts. Pp. 35-62 in D.F. Pocock, trans., Sociology and Philosophy. London: Cohen \& West Ltd. [1906] 1953b. Replies to objections. Pp. 63-79 in D.F. Pocock, trans., Sociology and Philosophy. London: Cohen \& West Ltd.

[1906] 1978. Divorce by mutual consent. Pp. 240-52 in Mark Traugott, trans., Emile Durkheim On Institutional Analysis. Chicago: The University of Chicago Press.

[1907] 1980a. Review. Marianne Weber, Ehefrau und mutter in der rechtsentwicklung. Eine einführung. Pp. 285-289 in Y. Nandam, ed., Emile Durkheim: Contributions to L'Année Sociologique. New York: The Free Press.

[1907] 1980b. Review. Charles Lefebvfre, Cours de doctorat sur l'histoire matrimoniale française. Pp. 218-221 in Y. Nandam, ed., Emile Durkheim: Contributions to L'Année Sociologique. New York: The Free Press.

[1909] 1979. A discussion on the notion of social equality. Pp. 65-76 in W.W.F. Pickering, ed., Durkheim: Essays in Moral Education. London: Routledge \& Kegan Paul.

[1914] 1973. The dualism of human nature and its social conditions. Pp. 149-63 in Robert N. Bellah, ed., Emile Durkheim: On Morality and Society. Chicago: University of Chicago Press.

[1950] 1992. Civic morals. Pp. 42-109 in Cornelia Brookfield, trans., Professional Ethics and Civic Morals. London: Routledge.

Emirbayer, Mustafa, ed. 2003. Emile Durkheim. Sociologist of Modernity. Oxford: Blackwell Publishing Ltd.

Farrell, R. Chad. 1997. Durkheim, moral individualism and the Dreyfus affair. Current Perspective in Social Theory 17:313-30.

Gane, Mike. 1983. Durkheim: Woman as outsider. Economy and Society 12(2):227-270.

1992. Durkheim: Woman as outsider. Pp. $85-132$ in The Radical Sociology of Durkheim and Mauss. New York: Routledge.

Gerhard, Ute. 2004. Illegitimate daughters: The relationship between feminism and sociology. Pp. 114-135 in Barbara L. Marshall and Anne Witz, eds., Engendering the Social: Feminist Encounters with Sociological Theory. New York: Open University Press. 
Giddens, Anthony. 1972. Introduction. Durkheim's writings in sociology and social philosophy. Pp. 1-50 in Emile Durkheim: Selected Writings. Cambridge: Cambridge University Press.

1986. Introduction. Pp. 1-31 in W.D. Halls, trans., Durkheim on Politics and the State. Cambridge: Polity Press..

Giner, Salvador. 1993. Religión Civil. Revista española de investigaciones sociológicas 61:23-55.

Harding, Sandra. 1991. Whose Science? Whose Knowledge? Ithaca, NY: Cornell University Press.

Hinson, S. Janet. 1994. Separate but equal: Durkheim's response to the woman question. Sociological Inquiry 64(1):23-36.

Inglis, David and Roland Robertson. 2008. The elementary forms of globality: Durkheim and the emergence and nature of global life. Journal of Classical Sociology 8(1):5-25.

Johnson, Barclay. 1972. Durkheim on women. Pp. 164-7 in N. Glazer-Malbin and Helen Y. Waehrer, eds., Woman in a Man-made World. Chicago: Rand McNally.

Kandal, R. Terry. 1988. The Woman Question in Classical Sociological Theory. Miami: Florida International University Press.

Keohane, Kieran. 2008. Moral education and cosmopolitanism: Meeting Kant and Durkheim in Joyce. Journal of Classical Sociology 8(2):262-82.

Kymlicka, Will. 2002. Contemporary Political Philosophy. New York: Oxford University Press Inc.

Landes, B. Joan. 1988. Women and the Public Sphere in the Age of the French Revolution. London: Cornell University Press.

Lehmann, M. Jennifer. 1990. Durkheim's response to feminism: Prescription for women. Sociological Theory 8(1):163-87. 1991. Durkheim's women: His theory of the structure and functions of sexuality. Current Perspective in Social Theory 11:141-67. 1994. Durkheim and Women. London: University of Nebraska Press. 1995. The question of caste in modern society: Durkheim's contradictory theories of race, class and sex. American Sociological Review 60(4):566585 .

Lemert, Charles. 2006. Durkheim's woman and the Jew as the pluperfect past of the good society. Pp. 124-143 in Durkheim's Ghosts: Cultural and Social Things. Cambridge: Cambridge University Press.

Llobera, R. Joseph. 1994. Durkheim and the national question. Pp. 134-58 in W.S.F. Pickering and H. Martins, eds., Debating Durkheim. London: Routledge. 2002. Political sociology. Pp. 69-79 in W.S.F. Pickering, ed., Durkheim Today. New York: Berghan Books. 
Lukes, Steven. 1973. Emile Durkheim, His Life and Work. London: Allen Lane Penguin Press.

Marske, E. Charles. 1987. Durkheim's cult of the individual and the moral reconstitution of society. Sociological Theory 5(1):1-14.

Meštrović, Stjepan. 1992. Durkheim and Postmodern Culture. New York: Aldine de Gruyter.

Nisbet, Robert. 1952. Conservatism and sociology. American Journal of Sociology 18:167-75.

Offen, Karen. 1984. Depopulation, nationalism, and feminism in fin-de-siècle France. American Historical Review 89:648-676.

Okin, Susan. 1979. Women in Western Political Thought. Princeton, NJ: Princeton University Press.

Pateman, Carole. 1988. The Sexual Contract. Oxford: Polity Press.

Pearce, Frank. 2001. The Radical Durkheim. Toronto: Canadian Scholars' Press Inc.

Pedersen, J. Elisabeth. 2001. Sexual politics in Comte and Durkheim: Feminism, history, and the French sociological tradition. Signs: Journal of Women in Culture and Society 27(1):228-262.

Pickering, W.S.F. 2002. Durkheim: The man himself and his heritage. Pp. 9-16 in W.S.F. Pickering, ed., Durkheim Today. New York: Berghahn Books.

Pickering, W.S.F. and H. Martins, eds. 1994. Debating Durkheim. London: Routledge.

Prager, Jeffrey. 1981. Moral integration and political inclusion: A comparison of Durkheim's and Weber's theories of democracy. Social Forces 59(4):918-50.

Ramp, J. William. 2001. Durkheim and the unthought: Some dilemmas of modernity. The Canadian Journal of Sociology 26(1):89-115.

Seidman, Steven. 1985. Modernity and the problem of meaning: The Durkheimian tradition. Sociological Analysis 46:109-30.

Shope, J. Hinson. 1994. Separate but equal: Durkheim's response to the woman question. Sociological Inquiry 64(1):23-36.

Smith, Dorothy. 1987. Women's perspective as a radical critique of sociology. Pp. 84-96 in Susan Harding, ed., Feminism and Methodology. Milton Keynes: Open University Press. 1992. Sociology from women's experience: A reaffirmation. Sociological Theory 10(1):88-98.

Stedman Jones, Susan. 2001. Durkheim Reconsidered. Cambridge: Polity Press.

Strenski, Ivan. 2006. The New Durkheim. New Brunswick, NJ: Rutgers University Press. 
Sydie, R.A. 1987. Natural Women, Cultured Men: A Feminist Perspective on Sociological Theory. New York: New York University Press.

2004. Sex and the sociological fathers. Pp. 36-53 in Barbara L. Marshall and Anne Witz, eds., Engendering the Social: Feminist Encounters with Sociological Theory. New York: Open University Press.

Terrier, Jean. 2006. The idea of a republican tradition: Reflections on the debate concerning the intellectual foundations of the French Third Republic. Journal of Political Ideologies 11(3):289-308.

Tiryakian, Eduard. 1981. Sexual anomie, social structure, societal change. Social Forces 59:1025-53.

Tole, Lisa Ann. 1993. Durkheim on religion and moral community in modernity. Sociological Inquiry 63(1):1-29.

Turner, S. Bryan. 1990. The two faces of sociology: Global or national? Theory, Culture and Society 7:343-58.

1992. Preface to the second edition. Pp. xiii-lxxiv in Emile Durkheim, Professional Ethics and Civic Morals, translated by Cornelia Brookfield. London and New York: Routledge.

2006. Classical sociology and cosmopolitanism: A critical defence of the social. The British Journal of Sociology 57(1):133-51.

Wallace, A. Ruth. 1973. The secular ethic and the spirit of patriotism. Sociological Analysis 34(1):3-11.

Wityak, Nancy and Ruth Wallace. 1981. Durkheim's non-social facts about primitives and women. Sociological Inquiry 51:61-7.

Witz, Anne and Barbara L. Marshall. 2004a. Introduction: Feminist encounters with sociological theory. Pp. 1-16 in Barbara L. Marshall and Anne Witz, eds., Engendering the Social: Feminist Encounters with Sociological Theory. New York: Open University Press.

2004b. The masculinity of the social: Towards a politics of interrogation. Pp.19-35 in Barbara L. Marshall and Anne Witz, eds., Engendering the Social: Feminist Encounters with Sociological Theory. New York: Open University Press.

Zeitlin, Irving. 1981. Ideology and the Development of Sociological Theory. Englewood Cliffs, NJ: Prentice-Hall.

Marcela Cristi received her Ph.D from the University of Waterloo. She currently teaches Sociology at Wilfrid Laurier University. She is the author of From Civil To Political Religion (2001), and has published several book chapters dealing with Durkheim's political sociology, and the use of religion in politics both in the United States and in global contexts. Her research specializations include classical sociological theory and sociology of religion. She is presently working on Durkheim's notion of democratic republicanism and citizenship.

mcristi@wlu.ca 